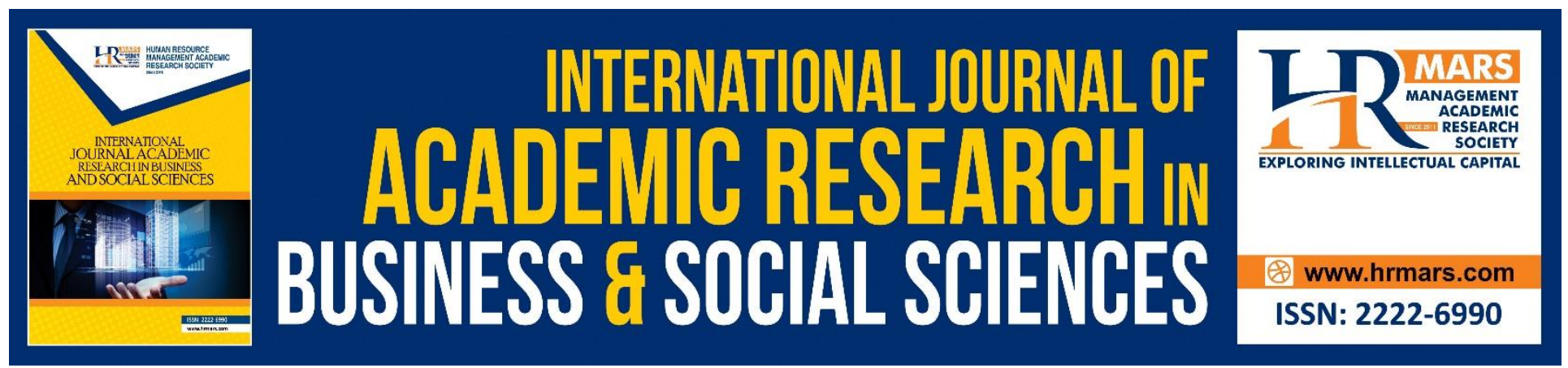

\title{
Diversification Strategy and Performance in Automotive Firms in Asean Countries
}

\begin{abstract}
Wan Mohd Nazri Wan Daud, Norfadzilah Rashid, Ahmad Husni Hamzah, Puspa Liza Ghazali, Farah Amalina Md Nawi
\end{abstract}

To Link this Article: http://dx.doi.org/10.6007/IJARBSS/v8-i12/5230

DOI: $10.6007 /$ IJARBSS/v8-i12/5230

Received: 28 Oct 2018, Revised: 16 Dec 2018, Accepted: 26 Dec 2018

Published Online: 29 Dec 2018

In-Text Citation: (Daud, Rashid, Hamzah, Ghazali, \& Nawi, 2018)

To Cite this Article: Daud, W. M. N. W., Rashid, N., Hamzah, A. H., Ghazali, P. L., \& Nawi, F. A. M. (2018). Diversification Strategy and Performance in Automotive Firms in Asean Countries. International Journal of Academic Research in Business and Social Sciences, 8(12), 1325-1336.

Copyright: (C) 2018 The Author(s)

Published by Human Resource Management Academic Research Society (www.hrmars.com)

This article is published under the Creative Commons Attribution (CC BY 4.0) license. Anyone may reproduce, distribute, translate and create derivative works of this article (for both commercial and non-commercial purposes), subject to full attribution to the original publication and authors. The full terms of this license may be seen

at: http://creativecommons.org/licences/by/4.0/legalcode

Vol. 8, No. 12, 2018, Pg. 1325 - 1336

http://hrmars.com/index.php/pages/detail/IJARBSS

JOURNAL HOMEPAGE

Full Terms \& Conditions of access and use can be found at http://hrmars.com/index.php/pages/detail/publication-ethics 


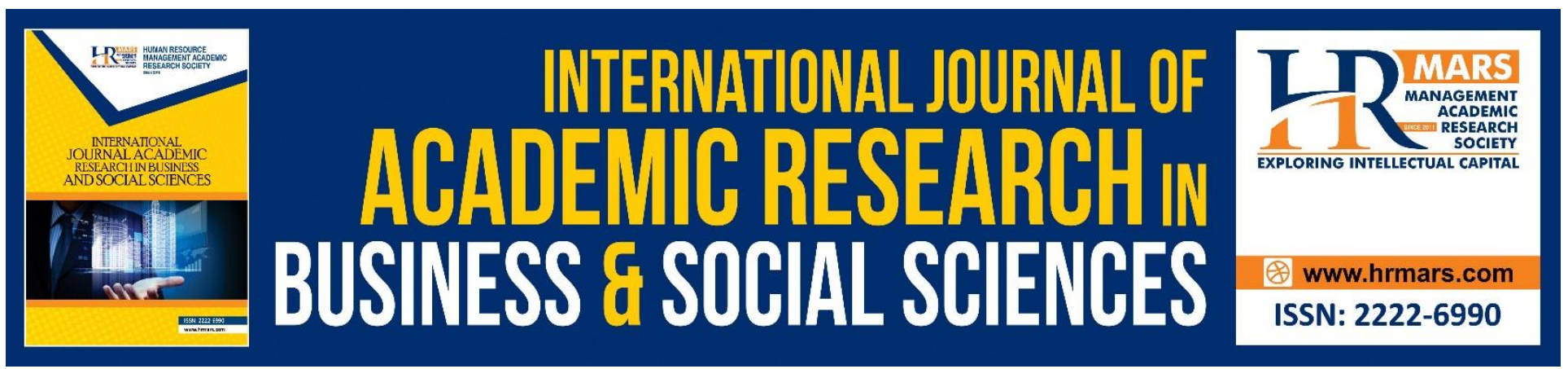

\title{
Diversification Strategy and Performance in Automotive Firms in Asean Countries
}

\author{
Wan Mohd Nazri Wan Daud, Norfadzilah Rashid, Ahmad Husni \\ Hamzah, Puspa Liza Ghazali, Farah Amalina Md Nawi \\ Faculty of Economics and Management Sciences, Universiti Sultan Zainal Abidin, 21300 Kuala Nerus, \\ Terengganu, Malaysia \\ Corresponding Author: farahamalina@unisza.edu.my
}

\begin{abstract}
Diversification strategy has been subjected to extensive research among strategic management and finance scholars. This study examines the effect of diversification strategy and performance in public listed automotive manufacturing firms in Asean countries using return on invested capital as a proxy of performance. The study uses panel data analysis for a sample of 28 Aseans' firms during the period 2007 to 2014 based on quarterly reporting data provided by Bloomberg database. The evidence produces interesting findings that related diversification has a significant effect on performance. In the meantime, several other variables show positive impact too. Therefore, automotive manufacturing firms should solely diversify around their core business to maintain their performance. Nevertheless, difference measures of performance should be adopted to check on consistency of the results.
\end{abstract}

Keywords: Earnings, Performance and Diversify.

\section{BACKGROUND}

Asean countries which comprises of 11 nations have population almost 600 million and combine gross domestic product of USD 2 trillion. These factors contribute positively to world growth (Afthanorhan, Awang, Rashid, Foziah, \& Ghazali, 2019). furthers add that Asean market could reach 55 million units of car by 2020. It demonstrates how importance of automotive sector to stimulate economic growth in this region. This sector has grown at $11 \%$ per annum in the last 5 years (20102014) where total sales of 3.2 million units were sold in 2014. It is expected that Asean region will become the sixth largest automotive market by 2018 (Zain, Abdullah, \& Rashid, 2018). In addition, stable political systems in this region enable these countries to attract foreign investment to invest in Asean. This region is considered hub not limited to automotive sector but many industries ranging from commodities, electronics, auto manufacturing and banking. Diversification strategy executes by Asean seem to bring more benefits to this region. This economic diversification implemented by 
INTERNATIONAL JOURNAL OF ACADEMIC RESEARCH IN BUSINESS AND SOCIAL SCIENCES Vol. 8, No. 12, Dec, 2018, E-ISSN: 2222-6990 @ 2018 HRMARS

Asean countries has created exciting growth in this region with forecasting annual growth of $5.4 \%$ per annum from 2014 to 2018 (N. Rashid, Asfthanorhan, Johari, Hamid, Yazid, Salleh, Abdullah, Ismail, Rasit, et al., 2018). With significant contribution of automotive sector to the Asean countries, this situation certainly brings benefit to the automotive firms in this region. Therefore, automotive firms may diversify their business strategy or remain doing related business in concentrated industry. Therefore, this paper examines the effect of diversification strategy on performance among public listed automotive manufacturing firms in Asean firms.

\section{DIVERSIFICATION STRATEGY AND PERFORMANCE}

Firms usually engage diversification strategy by implementing related and unrelated approach (Aziz et al., 2018). The acts of diversifying into related and unrelated business could only be done if firms have appropriate resources. Firms usually diversify into related business if they have physical and intangible resources. Meanwhile, they may diversify into unrelated business if they have sufficient financial resources (Alfadhli, Rashid, \& Yaakub, 2018). Related diversification is pursued due to creation of synergy as a result of diversifying around core business. Usually firms justify their implementation of related strategy to achieve synergy through the sharing of similar resources in order to obtain economies of scale. Efficient use of resources would result in more cost savings, lower production cost and provide them with a competitive edge over competitors. Thus, it could enhance performance as value created through sharing similar resources is better than value yields from separate use of those resources. It could be done through two major routes which are merger and acquisition or internal development. Growing internally means sharing similar resources that result from economies of scale leading to lower production cost through efficiency (Mansor, Akmal, Rashid, Ibrahim, \& Bakar, 2018).

Similar strategy also has been proposed as a method to improve performance in developed markets particularly in United States (N. Rashid, Zainol, Salleh, Endut, Yaakub, Ghazali, Afthanorhan, Rashid, \& Daud, 2018) and in Japan. They assert that firm in the said countries diversify around their core business and their performance increased. (Jamal, Daud, Zainol, Rashid, \& Afthanorhan, 2018) add that related firms are operating in profitable industries as compared to unrelated firms, thus, there is no reason for them to diversify into unrelated business. These profitable firms normally operate in mature industry where the best strategy for them is focused strategy (N. Rashid, Daud, Zainol, Salleh, Yazid, Endut, Yaakub, Ghazali, Afthanorhan, et al., 2018). Furthermore, capital-intensive nature of related firms would create better performance for the firms.

A strong rejection for implementation of unrelated strategy is demonstrated by ( $N$. Rashid, Daud, Zainol, Salleh, Yazid, Endut, Yaakub, Ghazali, Afthanorhan, et al., 2018) who emphasized that unrelated firms would result in low performance when the firm fails to make strategic investment. Further, they conclude that high performing firms are unlikely to implement unrelated strategy due to better investment opportunities as compared to firms experiencing low performance.

Meanwhile, other firms actively pursue unrelated strategy. Hence, the question remains if related diversification is a better strategy to improve performance. If that is the case, why do firms continue 
to implement unrelated strategy and its effect on performance? The reason for firms to execute that strategy could result from financial motive such as to stabilize their earnings and to have excess cash flow. These are two reasons related to financial resources that cause firms to execute unrelated strategy. Furthermore, firms can exploit market imperfection in developing countries to enhance performance (Musibau et al., 2018). Financial motive could be a reason for implementation of unrelated diversification. Unrelated firms usually have the capability to use internally generated funds in which an efficient use of those resources possibly would result in better performance. In addition, unrelated firms have the capacity to use external capital market to further improve their performance. Volatility of earnings in the current industry also causes firms to perform unrelated strategy. With motivation to reduce the volatility, firms decide to venture into other industries. All of these are done with the intention to enhance performance.

(Ali, Abdullah, \& Rashid, 2018) advocate that view by suggesting unrelated strategy recorded superior performance in Korean market compared to firms in United States. According to (Masud, Daud, Zainol, Rashid, \& Asyraf, 2018a), there are differences in implementing unrelated strategy in United States as compared to Korean market that could yield different outcomes for respective country.

\section{RESEARCH DESIGN}

This research begins with gathering data from Bloomberg database provided by Bursa Malaysia's Library. The firms are later identified and classified into related or unrelated groups based on recognized measurements. A dummy variable is used to differentiate between these two types of strategy, (related $=0$; unrelated $=1$ ). Several tests are done to measure normality, stability and reliability of the data through normality testing and stationary test. Each of these is important to ensure reliability of the data.

Subsequently, descriptive statistics that summarize the profile of data are analyzed together with correlation between variables to ensure the observed data is free from multicollinearity, autocorrelation and heteroscedasticity. Estimation models and methods are then developed to examine the relationship between independent and dependent variables. Multiple regression analysis then is used to examine the relationship between diversification strategy and performance. This study examines the impact of diversification strategy on firm performance specifically in the perspective of related and unrelated strategy. This study considers Ordinary Least Square (OLS) estimation technique only as it is regarded as the best estimation technique in measuring regression. Related strategy then is coded as 0 while unrelated strategy is coded as 1.

\section{DATA AND MEASUREMENT OF CONCEPTS}

The following sections discuss the sources of data and measurement of concepts used in this study. In the first sub-section, the discussion is on data collection procedures while in the second, the study elaborates a number of proxies for each variable so that analysis could be done. These proxies are adapted to develop the models to comprehend the relationship between various variables. 


\section{Sources of Data}

The main sources of data for the analysis in this study are from Bloomberg Database. These databases provide detailed financial information on Asean firms from 2010 until 2015. This sample of this study is the public listed firms in their main bourse in their respective countries particularly in automotive sectors. However, firms are eliminated due to several reasons such as missing data, serious discontinuation of their existing business, discontinuation of business operations due to mergers or acquisitions, firms with unassignable SIC code, firms without core business and distressed firms. In completing this study, industry segment is identifies using Standard Industry Classification (SIC) code whereby business count approach is used as adopted by Ishak and Napier (2004). This approach is more objective in measuring diversification strategy. Therefore, the study samples are manually matched with industry segments. Even though four digits SIC codes refer to product diversification, industrial diversification could be identified through similar SIC codes for example 2043 (Cereal Breakfast Foods) and 2044 (Rice Milling). Both SIC codes indicate two different product diversification but they are operating in a similar industry represented by the first two digit SIC codes 20 (Food and Kindred Product).

\section{ESTIMATION MODEL}

Estimation model are deployed in order to determine the relationship between diversification and performance. This model is formed in order to observe the relationship between diversification strategy, which is identified using dummy variable whereby 0 for related strategy and 1 for unrelated strategy.

The following model is adopted from (Mahmod et al., 2018). They classified the firms into four types of strategy; single, dominant, related and unrelated, then run each type of strategy separately with the dependent variable. Those strategies acted as implicit dummy. Nevertheless, the present study uses the suggestion by (Masud, Daud, Zainol, Rashid, \& Asyraf, 2018b) to differentiate between the effects of each strategy on performance. Two major categories is used, related and unrelated following approach the used by (Noor, Norhayate, Rashid, \& Asyraf, 2018) in developing countries and (Shams et al., 2018) in India.

\section{Model 1}

$$
\text { Perf }_{i t}=\alpha_{0 i}+\beta_{1} \text { size }_{i t}+\beta_{2} \text { liq }_{i t}+\beta_{3} \text {TDA}_{i t}+\beta_{4} s_{i t}+\grave{e ̀}_{i 2 t} \quad \text { Eq } 9
$$

Where :

PERF: performance is proxied by return on asset

TDA : debt is proxied by total debt over total asset

SIZE: size is proxied by logarithm of total asset

LIQ: liquidity is proxied by current assets over current liabilities

SD: Strategy dummy where related $=0$ and unrelated $=1$ 
Meanwhile, $t=$ time period under review, $i=1,2 \ldots n$ firms and the $\beta$ is the unknown coefficients to be estimated and $\grave{e ̀}_{i t}$ is a random error term which is assumed to be independently and identically distributed with a normal distribution having zero mean and variance $\sigma^{2}$.

\section{HYPOTHESES}

The argument is over which strategy could be used to enhance performance, either related or unrelated. Both strategies have their own disciples and they justified based on empirical evidence from their studies. They also claim that their choice of strategy is the best to enhance firms' performance. Hence, this hypothesis investigates the relationship between these two variables.

\section{$H_{0}$ : there is no relationship between diversification strategy and performance.}

Two streams of empirical studies have their own evidence from respective studies. The first stream indicates related strategy performs better and should be used to enhance performance (Noor et al., 2018). All of them suggest that performance could be improved once firms diversify around their core businesses.

In contrast, other studies suggest unrelated strategy is better technique to diversify in developing countries among them (N. Rashid, Fara, Kamal, Hamid, Ghazali, Yusop, Zaid, Rashid, Fara, et al., 2018). These studies recommend developing countries firms should implement unrelated strategy to enhance performance as these countries still experience market imperfections. These imperfections could relate to easy access to goods and services, inadequate core competency among firms and favorable government policy that allow diversified strategy to be most appropriate strategy in a developing country (Yazid et al., 2017).

\section{DESCRIPTIVE STATISTIC}

The descriptive statistic in Table 4.1 is used to check normality of the data. This table presents and analyses the means, medians, and standard deviations, skewness, kurtosis (the height) and JarqueBera (the variation of the distributions) for each variable used in the sample. The expected value for skewness test should equal to 0 and the kurtosis value should not exceed three so that the data is assumed to be normal. After that, the value of JarqueBera should not be significant $(p<=0.05)$. By meeting the said assumption, sample data is identified as an efficient estimator, unbiased and

consistent. Meanwhile, violation of the assumption means the sample data is not normally distributed.

The information is provided return on invested capital (ROIC, total debt (DEBT), liquidity (QRC), capital expenditure (CAPEX) and firm size (SIZE). Table 4.2 shows a small distribution of data indicated by mean and median for each variable. 
INTERNATIONAL JOURNAL OF ACADEMIC RESEARCH IN BUSINESS AND SOCIAL SCIENCES Vol. 8, No. 12, Dec, 2018, E-ISSN: 2222-6990 @ 2018 HRMARS

Table 4.1 Descriptive Statistics

\begin{tabular}{llllll}
\hline & CAPEX & DEBT & QRC & ROIC & SIZE \\
\hline Mean & -4.627917 & 19.03903 & 1.741959 & 7.293706 & 3.739649 \\
Median & -0.722784 & 13.29809 & 1.166200 & 6.540200 & 3.244318 \\
Maximum & 0.040000 & 73.60075 & 18.97450 & 35.94080 & 8.373649 \\
Minimum & -504.9289 & 0.000000 & 0.135500 & 1.712532 & $(0.0000)$ \\
Std. Dev. & 24.54433 & 17.80547 & 2.054987 & 7.363739 & 1.815404 \\
Skewness & -17.97033 & 0.746451 & 3.894692 & -0.765394 & 0.976971 \\
Kurtosis & 351.0703 & 2.468020 & 22.05983 & 11.30197 & 2.712019 \\
Jarque-Bera & 4571269. & 93.77228 & 15827.53 & 2660.596 & 145.6307 \\
\hline Probability & 0.000000 & 0.000000 & 0.000000 & 0.000000 & 0.000000 \\
\hline Sum & -4146.614 & 17058.97 & 1560.795 & 6535.161 & 3350.726 \\
\hline Sum Sq. Dev. & 539169.7 & 283746.1 & 3779.558 & 48531.07 & 2949.645 \\
\hline Observations & 896 & 896 & 896 & 896 & 896 \\
\hline
\end{tabular}

Note: Figure in parenthesis is the $\rho$ value.

***Significant at 0.01 level

\section{EMPIRICAL RESULTS}

The following result in Table 4.2 is based Ordinary Least Square (OLS) estimation technique to examine the relationship between diversification strategy and performance. This work is encouraged by conflicting evidence over which strategy is a better performer.

Diversification strategy is classified into related and unrelated strategy and then it is identified using dummy variable as 0 and 1 respectively. Return on asset is selected as a proxy of performance. Other variables such as liquidity, capital expenditure, strategy dummy debt and size are used as the control variables. The tests show that the models are significant at $1 \%$. 
INTERNATIONAL JOURNAL OF ACADEMIC RESEARCH IN BUSINESS AND SOCIAL SCIENCES

Vol. 8, No. 12, Dec, 2018, E-ISSN: 2222-6990 @ 2018 HRMARS

Table 4.2: OLS Estimation Result

\begin{tabular}{cc}
\hline Variable & ROIC \\
\hline Constant & $6.3690^{* * *}$ \\
LIQ & $(0.0000)$ \\
& $-0.2557^{* *}$ \\
SIZE & $(0.0401)$ \\
& $0.9444^{* * *}$ \\
TDA & $(0.0000)$ \\
& $-0.0257^{*}$ \\
CAPEX & $(0.0786)$ \\
& $0.1017^{* * *}$ \\
SD & $(0.0000)$ \\
& $-2.4029 * * *$ \\
N & $(0.0000)$ \\
R2 & 896 \\
Adj. R2 & $20.75 \%$ \\
P & $20.31 \%$ \\
DW & 46.6119 \\
\hline
\end{tabular}

Note: Figure in parenthesis is the $\rho$ value **Significant at 5 percent level

***Significant at 1 percent level *Significant at 10 percent level

The R2 exhibits the variance in performance is explained by independent variables at $20.75 \%$ for all models. R2 is usually used to give information relating to goodness of fit for that model and predicted the outcome based on that information. Therefore, the result shows that there is a negative relationship between diversification strategy and performance. It means that related strategy is a better performer than unrelated strategy in automotive sector. This is consistent with a number of studies such as (Rashid, Sulong, \& Rahman, 2016).

The result also shows that liquidity is negatively related to performance which means high level of liquidity may result in mismanage of fund in order to enhance earnings to the firms. This is consistent with (Sabiu et al., 2018) who indicate misappropriate of money if firms have excessive liquidity in the firms. Similarly, debt also has negative impact on the firms. Therefore, firms should avoid from taking excessive debt that could dampen future business growth as highlighted in literature.

As for size and capital expenditure, the results indicate large firm's size could give more flexible for the management to maneuver the direction of firms to enhance performance. (Johari, Rashid, \& Yazid, 2018) view positive size effect on performance as they assert that large firms could use their resources more efficiently to achieve the goal of the firm. In the meantime, firms should spend more on capital expenditure to improve earnings to the firms. It is clearly indicate that firms with more 
INTERNATIONAL JOURNAL OF ACADEMIC RESEARCH IN BUSINESS AND SOCIAL SCIENCES

Vol. 8, No. 12, Dec, 2018, E-ISSN: 2222-6990 @ 2018 HRMARS

capital spending would improve performance. This is consistent with (Ismail et al., 2018) that assert the importance of capital spending to enhance growth of the firms.

\section{DISCUSSION AND CONCLUSION.}

This study starts with several tests are conducted such as normality test using descriptive statistics. The result indicates that debt is negatively related to performance. This is consistent with other studies such as (Alfadhli et al., 2018).

In the meantime, the result shows that there is a positive relationship between related strategy and performance. The result of this study is consistent with other researches such as (Liu, 2018)]. According to (Alfadhli et al., 2018), related strategy as the most suitable strategy used to improve performance and reduce risk. This is supported by (Usop et al., 2018) in doing their research in developing countries who suggest firms to implement related over unrelated strategy to improve performance.

Unrelated strategy could be implemented to improve performance if debt is excluded from the firms. It means that unrelated firms should consider not using debt in execution of business strategy as debt brings negative effect to the firms. Excessive uses of debt among unrelated firms bring performance deterioration to the firms.

\section{FUTURE RESEARCH}

Another element that possibly requires further investigation is related to the combination effect of diversification strategy and debt on performance. Earlier finding has advocated that unrelated firms could well performed, if they do not adopt debt in the capital structure as debt has been found to be negatively related to performance. Ignoring debt could seem impractical as most firms use debt to enhance performance. In addition, automotive sectors require huge amount of money to produce new design and prototype of the car which then require internal fund or debt financing to support those business activities. Therefore, the combination effect of diversification strategy and debt on performance should be continuously researched.

Industry effect also needs to be considered as firms, which operate in profitable industry, would not leave industry in pursuing risky businesses (Norliana, Fakhrul Anwar, Wan Norhayate, Norfadzilah, \& Asyraf, 2018). The importance of industry effect has been advocated by [8] who claimed that operating in poor growth industry and weak cash flow deteriorate firms' performance. Future research should include industry effect in examining the relationship between diversification strategy and performance. Furthermore, the dynamics of diversification strategy should also be considered for future research as firms possibly have to change their diversification strategy depending on the environment during that particular time. 
INTERNATIONAL JOURNAL OF ACADEMIC RESEARCH IN BUSINESS AND SOCIAL SCIENCES

Vol. 8, No. 12, Dec, 2018, E-ISSN: 2222-6990 @ 2018 HRMARS

\section{References}

Afthanorhan, A., Awang, Z., Rashid, N., Foziah, H., \& Ghazali, P. L. (2019). Assessing the effects of service quality on customer satisfaction. Management Science Letters, 9(1), 13-24. http://doi.org/10.5267/j.msl.2018.11.004

Alfadhli, M. I., Rashid, N., \& Yaakub, N. (2018). The Impact of Internal Audit and its Quality on Sales in Economic Institutions: A Case Study ( Al-Ahlia Cement Company - Libya) The Impact of Internal Audit and its Quality on Sales in Economic Institutions : A Case Study ( Al-Ahlia Cement Company - Lib. International Journal of Academic Research in Business and Social Sciences, 8(8), 50-65. http://doi.org/10.6007/IJARBSS/v8-i8/4434

Ali, A. R., Abdullah, B., \& Rashid, N. (2018). An Error Analysis Approach in Identifying the Patterns of Mistakes in Jawi Spelling An Error Analysis Approach in Identifying the Patterns of Mistakes in Jawi Spelling. International Journal of Academic Research in Business and Social Sciences, 8(11), 1222-1231. http://doi.org/10.6007/IJARBSS/v8-i11/5164

Aziz, K. A., Yazid, A. S., Mahmod, M. S., Rashid, N., Salleh, F., \& Ghazali, P. L. (2018). Enterprise Risk Management ( ERM ) Practices among Malaysian SMEs : The Three Steps Process to identify Adopters and Non- Adopters of ERM for SMEs Enterprise Risk Management ( ERM ) Practices among Malaysian SMEs : The Three Steps Process to identify Adop. International Journal of Academic Research in Business and Social Sciences, 8(11), 1232-1245. http://doi.org/10.6007/IJARBSS/v8-i11/5165

Ismail, M., Zainol, F. A., Norhayate, W., Daud, W., Rashid, N., \& Afthanorhan, A. (2018). Application of Entrepreneurial Marketing to the Marketing Mix : Why it Matters to SMEs in Malaysia? Application of Entrepreneurial Marketing to the Marketing Mix : Why it Matters to SMEs in Malaysia ? International Journal of Academic Research in Business and Social Sciences, 8(12), 850-865. http://doi.org/10.6007/IJARBSS/v8-i12/5079

Jamal, R., Daud, W. N. W., Zainol, F. A., Rashid, N., \& Afthanorhan, A. (2018). Unlocking " Black Box ": Mediating Role of Knowledge Process Capability on HRM Practices and Innovative Performance Unlocking "Black Box ": Mediating Role of Knowledge Process Capability on HRM Practices and Innovative Performance. International Journal of Academic Research in Business and Social Sciences, 8(11), 1192-1208. http://doi.org/10.6007/IJARBSS/v8-i11/5162

Johari, R. J., Rashid, N., \& Yazid, A. S. (2018). An Empirical Examination of Undergraduate Accounting Students ' Ethical Judgment : Malaysia Evidence An Empirical Examination of Undergraduate Accounting Students ' Ethical Judgment : Malaysia Evidence. International Journal of Academic Research in Business and Social Sciences, 8(12), 669-681. http://doi.org/10.6007/IJARBSS/v8-i12/5064

Liu, S. (2018). Earnings management and institutional investor trading prior to earnings announcements. China Finance Review International, CFRI-01-2018-0010. http://doi.org/10.1108/CFRI-01-2018-0010

Mahmod, M. S., Aziz, K., Yazid, A. S., Rashid, N., Salleh, F., \& Ghazali, P. L. (2018). A Conceptual Framework of ERM Practices among SMEs IN Malaysia A Conceptual Framework of ERM Practices among SMEs IN Malaysia. International Journal of Academic Research in Business and Social Sciences, 8(11), 1209-1221. http://doi.org/10.6007/IJARBSS/v8-i11/5163 
INTERNATIONAL JOURNAL OF ACADEMIC RESEARCH IN BUSINESS AND SOCIAL SCIENCES Vol. 8, No. 12, Dec, 2018, E-ISSN: 2222-6990 @ 2018 HRMARS

Mansor, M., Akmal, F., Rashid, N., Ibrahim, R. M., \& Bakar, N. A. (2018). The Impact of Human Resouce Practises, Leadership Style And Religiousity on Cyber Deviance The Impact Of Human Resouce Practises, Leadership Style And Religiousity On Cyber Deviance. International Journal of Academic Research in Business and Social Sciences, 8(11), 1283-1293. http://doi.org/10.6007/IJARBSS/v8-i11/5169

Masud, H., Daud, W. N. W., Zainol, F. A., Rashid, N., \& Asyraf, A. (2018a). A critique of normative commitment in management research. International Journal of Academic Research in Business and Social Sciences, 8(11), 1172-1191. http://doi.org/10.6007/IJARBSS/v8-i11/5161

Masud, H., Daud, W. N. W., Zainol, F. A., Rashid, N., \& Asyraf, A. (2018b). Human resource management practices and organizational commitment: research methods, issues and future directions (2001-2016). International Journal of Academic Research in Business and Social Sciences, 8(11), 1134-1148. http://doi.org/10.6007/IJARBSS/v8-i11/5159

Musibau, H. O., Mahmood, S., Ismail, S., Shamsuddin, Z., Rashid, N., \& Mahmood, S. (2018). Does External Debt Cause Economic Growth ? An Experience from ECOWAS Member Countries Does External Debt Cause Economic Growth ? An Experience from ECOWAS Member Countries. International Journal of Academic Research in Business and Social Sciences, 8(11), 1256-1264. http://doi.org/10.6007/IJARBSS/v8-i11/5167

Noor, N., Norhayate, W., Rashid, N., \& Asyraf, A. (2018). Exploring the Predominant Qualities of Head Teachers towards Achieving School Success Exploring the Predominant Qualities of Head Teachers towards Achieving School Success. International Journal of Academic Research in Business and Social Sciences, 8(11), 1324-1330. http://doi.org/10.6007/IJARBSS/v8-i11/5173

Norliana, A. M., Fakhrul Anwar, Z., Wan Norhayate, W. D., Norfadzilah, R., \& Asyraf, A. (2018). Entrepreneurial Intention from the Islamic Perspective : A Holistic Approach Entrepreneurial Intention from the Islamic Perspective : A Holistic Approach. International Journal of Academic Research in Business and Social Sciences, 8(12), 820-833. http://doi.org/10.6007/IJARBSS/v8i12/5077

Rashid, N., Asfthanorhan, A., Johari, R. J., Hamid, N. A., Yazid, A. S., Salleh, F., ... Salleh, F. (2018). Ethics and Financial Reporting Assurance. International Journal of Academic Research in Business and Social Sciences, 8(11), 1346-1355. http://doi.org/10.6007/IJARBSS/v8-i11/5176

Rashid, N., Daud, W. N. W., Zainol, F. A., Salleh, F., Yazid, A. S., Endut, W. A., ... Abdullah, B. (2018). The Stakeholders Perceptions towards the Corporate Social Responsibility Reporting The Stakeholders Perceptions towards the Corporate Social Responsibility Reporting. International Journal of Academic Research in Business and Social Sciences, 8(11), 1303-1310. http://doi.org/10.6007/IJARBSS/v8-i11/5171

Rashid, N., Daud, W. N. W., Zainol, F. A., Salleh, F., Yazid, A. S., Endut, W. A., ... Ghazali, P. L. (2018). The Uses of Financial Reporting Standard for Small Medium Enterprise Companies The Uses of Financial Reporting Standard for Small Medium Enterprise Companies. International Journal of Academic Research in Business and Social Sciences, 8(11), 1331-1338.

http://doi.org/10.6007/IJARBSS/v8-i11/5174

Rashid, N., Fara, N., Kamal, S., Hamid, N. A., Ghazali, N., Yusop, R., ... Abd, N. (2018). The Effect of Government Support Programs and Compliance Costs on Goods and Services Tax Compliance among Malaysian Batik Manufacturers The Effect of Government Support Programs and 
INTERNATIONAL JOURNAL OF ACADEMIC RESEARCH IN BUSINESS AND SOCIAL SCIENCES

Vol. 8, No. 12, Dec, 2018, E-ISSN: 2222-6990 @ 2018 HRMARS

Compliance Costs on Goods and Services Tax Compliance among Malaysian Bat. International Journal of Academic Research in Business and Social Sciences, 8(12), 682-694. http://doi.org/10.6007/IJARBSS/v8-i12/5065

Rashid, N. M. N. N. M., Sulong, Z., \& Rahman, C. A. (2016). Interconnections issues of accounting, Finance and Economics in the Capital Market Transaction. (N. M. N. N. M. Rashid, Z. Sulong, \& C. A. Rahman, Eds.). Terengganu, Malaysia: Penerbit UniSZA.

Rashid, N., Zainol, F. A., Salleh, F., Endut, W. A., Yaakub, N., Ghazali, P. L., ... Daud, W. N. W. (2018). Quality of Financial Reporting towards the Improvement Corporate Governance Mechanism Quality of Financial Reporting towards the Improvement Corporate Governance Mechanism. International Journal of Academic Research in Business and Social Sciences, 8(11), 1339-1345. http://doi.org/10.6007/IJARBSS/v8-i11/5175

Sabiu, I. T., Zainol, F. A., Norhayate, W., Daud, W., Rashid, N., Afthanorhan, A., ... Zainol, F. A. (2018). Big Five Personality Characteristics : An Exploratory Study on Bumiputra SMEs in Malaysia Big Five Personality Characteristics : An Exploratory Study on Bumiputra SMEs in Malaysia. International Journal of Academic Research in Business and Social Sciences, 8(12), 866-881. http://doi.org/10.6007/IJARBSS/v8-i12/5080

Shams, A., Hoque, M. M., Awang, Z. Bin, Muda, H., Salleh, F., \& Rashid, N. (2018). Ramification of crowdfunding on Bangladeshi entrepreneur's self-efficacy. International Journal of Academic Research in Business and Social Sciences, 8(12), 129-138. http://doi.org/10.5267/j.ac.2018.04.001

Usop, R., Zainol, F. A., Chik, Z., Norhayate, W., Daud, W., Rashid, N., \& Afthanorhan, A. (2018). Competitive Advantage and Performance : Empirical Investigation on Demographic Factors of Malaysian Hotel Entrepreneurs Competitive Advantage and Performance : Empirical Investigation on Demographic Factors of Malaysian Hotel Entrepreneurs. International Journal of Academic Research in Business and Social Sciences, 8(12), 810-819. http://doi.org/10.6007/IJARBSS/v8-i12/5067

Yazid, A. S., Ariffin, J., Awang, Z., Daud, W. N. W., Zainol, F. A., Salleh, F., ... Hamid, N. A. (2017). Does Education Moderates the Relationship Between Decision Factors and Purchase Decision of Family Takaful Protection in Malaysia ? World Applied Sciences Journal, 35(9), 1849-1863. http://doi.org/10.5829/idosi.wasj.2017.1849.1863

Zain, F. A. M., Abdullah, W. A. W., \& Rashid, N. (2018). The Mediating Role of Environmental Performance on The Relationship Between Corporate Governance Mechanisms and Environmental Disclosure. Asian Academy of Management Journal of Accounting and Finance, 14(1), 153-183. http://doi.org/10.21315/aamjaf2018.14.1.7 